\title{
Character Building Since Early Childhood Through Story Telling About Folklore
}

\author{
Ana Mentari ${ }^{1, *}$ Hermi Yanzi ${ }^{1}$ Nopiana $^{2}$ \\ ${ }^{1}$ Department of Civic Education, Universitas Lampung, Bandar Lampung, Indonesia \\ ${ }^{2}$ Department of Early Childhood Education, Universitas Lampung, Bandar Lampung, Indonesia \\ *Corresponding author. Email: ana.mentari@fkip.unila.ac.id
}

\begin{abstract}
The Indonesian nation must be built by prioritizing character development because this character building will make Indonesia a great, advanced, and glorious, dignified nation. Today the rapid progress and sophistication of technology makes habits begin to be abandoned. Children now prefer to play gadgets and play stations rather than traditional children's games, whereas traditional children's games are not just games but also teaches about many lessons such as practicing patience, cooperation, responsibility, tolerance, and caring among others. Therefore, it is necessary to plant good character traits early on in early childhood, with the hope that good character can be well embedded early on. Character is not formed by learning in class, but it requires habituation. Through storytelling it is hoped that children will recognize, understand and be able to feel the values contained in the story, so good character values will be embedded in the child. The habit of telling stories or storytelling about folklore needs to be done at school, especially at home, so that communication between teachers, parents, and children can be established in instilling the children's character.
\end{abstract}

Keywords: Early childhood, character building, story telling, floklore

\section{INTRODUCTION}

The development of a child is a golden development period that needs to be maximized in the child's potential either intellectually, emotionally and spiritually, for the sake of children's growth and character at a mature age. So that the inculcation of character values in children must

Table 1 Portraits building neglected characters follow the world of children, and they need adult supervision. Most child growth and development lack family roles and many parents leave their children in daycare, study groups, and kindergartens. Portraits building neglected characters (Soedarsono, 2009; Samani \& Hariyanto, 2016).

\begin{tabular}{|l|l|l|l|}
\hline & Home & School & Society \\
\hline Old Age Wisdom & Increased spiritual approach & $?$ & Many are apathetic \\
\hline Stabilization of Adult Age & $?$ & $!$ & $\begin{array}{l}\text { Low trust society do not } \\
\text { respect the scarcity of } \\
\text { role models }\end{array}$ \\
\hline Adolescent Development & $?$ & $!$ & $\begin{array}{l}\text { Not conducive, } \\
\text { orientation to money, } \\
\text { material and worldly }\end{array}$ \\
\hline Early Age Establishment & Many are left to the Maid & $!$ & Not conducive \\
\hline
\end{tabular}

The education world has crucial problems faced including the multidimensional crisis, moral character degradation, and the issue of national disintegration. So that character education is considered to be a viable alternative solution to dealing with the nation's moral problems which are getting worse (Nurmalisa, Mentari, Nurhayati, \& Yanzi, 2019). The current phenomenon is that we often find children no longer respecting their parents, adolescent free promiscuity, and having anti-social attitudes that appear from daily life both at school and society. 
The rapid progress and sophistication of technology that is happening today makes habits begin to be abandoned. Children now prefer to play gadget and play station rather than traditional children's games. Traditional children's games are not just games but also teach about many lessons such as practicing patience, cooperation, responsibility, tolerance, and caring among others.
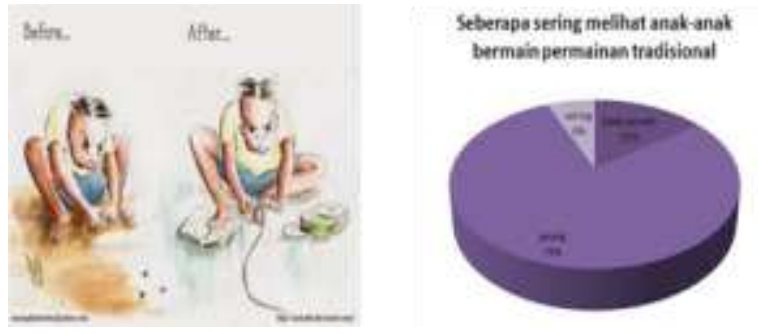

Figure 1 Children prefer to play gadget and play station rather than traditional children's games

So, the inculcation of character values from an early age through folklore can become a more friendly approach with children. Because we're not only telling stories with them but there is also the value of attachment, inner attachment, transfer of good values, and the early introduction of local culture to children.

This article focuses on Lampung's folklore because the research site is set in Lampung. Thus, the introduction of local culture early on in children manifested from the surrounding environment. We tell folklore that have character values in it.

\section{METHOD}

The method used in this research is constructivist method with a qualitative approach. Constructivist approach to early childhood education focus on developmentally appropriate practice for children from birth to eight years of age (Bredekamp, 1987; Bredekamp \& Copple, 1987). The Goal of constructivist is to promote children's development in all areas of the curriculum (science, mathematics, language and literacy, social studies, and the arts), and all development domains (intellectual, physical, social, emotional, and moral) (Fosnot, 2005; DeVries, Zan, Hildebrandt, Edmiaston, \& Sales, 2002). Apart from that, Constructivist also aims to create a sociomoral atmosphere where mutual respect is continually practiced. "sociomoral atmosphere" refers to the entire network of interpersonal relations in the classroom (child-child relationships, adultchild relationships, and adult-adult relationships) observable by children (DeVries, \& Zan, 1994). The research was conducted at Dharma Wanita Kindergarten of Universitas Lampung, by conducting direct observations in TK B classes totaling 20 people. Observations are made by observing the behavior of children in the classroom and outside the classroom. We give the children the story of folklore twice a week. Folklore that was delivered varied from Lampung folklore to popular folklore in every region of Indonesia which has positive values.

\section{RESULT AND DISCUSSION}

Character education programs have gained increasing interest in the past decade and are designed to produce students who are thoughtful, ethical, morally responsible, community oriented, and self-disciplined (Rawana, Franks, Brownlee, Rawana, \& Neckoway, 2011). Character education that is implanted certainly leads to good morality and all things positive. Therefore, character education needs to be done in education both from education in schools, colleges, homes, and the community. Especially today, during what is known as the Industrial Revolution 4.0, with increasingly advanced information and technology developments followed by millennial generation. The generation that makes the most of technology in daily life. Thus, the positive influence of character education can be used as provision for student life behavior in an era that is prone to moral degradation.

Character education is expected to overcome the crisis that occurs in the character of the global community and play a role in developing human potential optimally as well as develop patterns of thought and behavior of students who are responsible for the conduct of social roles in the family, society and citizens (Dwiningrum, 2013). Character education is expected to overcome the crisis that occurs in the character of global society and develop the citizens potential optimally and develop the mindset and behavior of citizens who are responsible for the implementation of social roles in the family, society, and as citizens who certainly do not deviate from the rules the cultural norms of Indonesian people who are guided by Pancasila.

Dewantara suggested ways to educate children through, giving examples (voorbeeld); habituation (pakulin, gewoontevorming); teaching (leering); orders, coercion and punishment (regeering en tucht); behavior (zelfbeheersching, zelfdicilpine); physical and mental experiences (ngerti, ngrasa, nglakoni) (Dewantara, 2013; Mentari, 2017). In addition, Ki Hajar Dewantara habituates the character values of children by "understanding, acting" (realizing, recognizing, and doing), so that children are truly able to understand and interpret every value conducted from each story given (Dewantara, 1977).

Dewantara formulated an education based on the nation's culture because both in its implementation of cultural education and national education were inseparable from the spirit of nationality to lead to the nobility and sanctity of inner life, as well as order and peace of life.

The hope is that the children of our nation are citizens who have character and have a sense of nationality towards their nation because they understand and feel the spirit of Indonesian nationality because every Indonesian citizen is a national ambassador when he goes to a foreign country.In order for cultural and national education to be able to function properly, an education center is needed. 


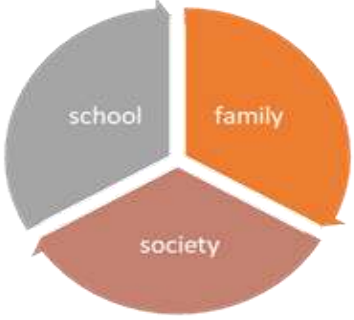

Figure 2 School, family and society an education center is needed

Through storytelling or telling stories about folklore, it is expected that children will recognize, understand and be able to feel the values contained in the story, so that good character values will be embedded in the child.

The habit of telling stories or telling stories about folklore needs to be done at school, especially at home, so that communication between teachers, parents, and children can be built in instilling the children's character.

\subsection{Early Childhood Character Planting through Folklore}

The method used by constructivists in instilling the character of early childhood through folklore. So that we can improvise in the story by changing facial expressions, gestures, changing the tone of the voice like the situation in the story, so that children can follow and feel that they are present in the story that we tell. One of the folklores that was told to children is as follows.

Asal Usul Kota Lampung (Prahara, 2015).

Menurut cerita, di daerah yang kini disebut Tapanuli. Meletuslah sebuah gunung berapi. Karena letusannya sangat hebat, banyak penduduk mati akibat semburan api lahar, dan batu-batuan dari gunung berapi itu. Akan tetapi, banyak juga yang berhasil menyelamatkan diri. Meletusnya gunung berapi di Tapanuli itu, menurut cerita membentuk sebuah danau yang sekarang disebut Danau Toba.

Ada empat orang bersaudara di antaranya yang berhasil selamat dari letusan gunung berapi itu. Mereka menyelamatkan diri dan meninggalkan Tapanuli menuju arah tenggara. Mereka naik sebuah rakit menyusuri pantai bagian barat Pulau Swarnadwipa, sekarang bernama Pulau Sumatera.

Keempat bersaudara itu bernama Ompong Silitonga, Ompung Silamponga, Ompung Silaitoa, dan Ompung Sintalanga. Berhari-hari mereka berlayar dengan rakit untuk menghindari letusan gunung berapi di kampung. Siang malam mereka tidur di atas rakit, terus menyusuri pantai. Berbulan-bulan mereka terombangambing di laut karena perjalanan mereka tanpa tujuan. Persediaan makanan yang dibawa makin lama makin menipis. Beberapa kali empat bersaudara itu singgah dan mendarat di pantai untuk mencari bahan makanan. Entah karena apa, pada suatu hari ketiga saudara Ompung Silamponga tidak mau melanjutkan perjalanan, padahal Ompung Silamponga saat itu sedang sakit. Mereka turun ke darat dan menghanyutkan Ompung Silamponga dengan rakit yang mereka tumpangi sejak dari Tapanuli. Berhari-hari Ompung Silamponga tidak sadarkan diri di atas rakitnya.

Akirnya pada suatu hari, Ompung Silamponga terbangun karena ia merasakan rakitnya menghantam suatu benda keras. Setelah membuka mata, Ompung Silamponga kaget. Rakitnya sudah berada di sebuah pantai yang ombaknya tidak terlalu besar. Anehnya, Ompung Silamponga merasa badannya sangat segar. Segera ia turun ke pasir, melihat ke sekeliling pantai. Dengan perasaan senang, ia tinggal di pantai itu. Kebetulan di sana mengalir sebuah sungai berair jernih. Ompung berpikir, di situlah tempatnya yang terakhir, aman dari letusan gunung berapi. Ia tidak tahu sudah berapa jauh ia berlayar. Ia juga tidak tahu di mana dimana saudaranya-saudaranya tinggal.

Cukup lama, Ompung tinggal di daerah pantai, tempatnya terdampar. Menurut cerita, tempat terdampar Ompung Silamponga dulu itu, kini bernama Krui, terletak di Kabupaten Lampung Barat, tepatnya di pantai barat Lampung atau disebut dengan daerah pesisir. Setiap hari Ompung bertani, yang bisa menghasilkan bahan makanan. Tidak disebutkan apa jenis tanaman yang ditanam Ompung saat itu.

Karena sudah lama tinggal di daerah pantai, ingin rasanya Ompung berjalan-jalan mendaki pegunungan di sekitar tempat tinggalnya. Semakin jauh Ompung masuk ke hutan, semakin senang ia melakukan perjalanan seorang diri.

Pada suatu hari, sampailah Ompung di suatu bukit yang tinggi. Dengan perasaan senang, ia memandang ke arah laut, lalu ke arah timur dan selatan. Ia sangat kagum melihat keadaan alam di sekitar tempatnya berdiri, apalagi di kejauhan tampak dataran rendah yang sangat luas.

Karena hatinya begitu gembira, tidak disadarinya ia berteriak dari atas bukit itu, "Lappung....Lappung....Lappung!" Kata Lappung berarti luas dalam bahasa Tapanuli. Dalam hati, Ompung, pasti disekitar dataran rendah yang luas itu ada orang. Dengan tergesa-gesa, ia menuruni bukit dan menuju dataran rendah yang ia lihat dari atas bukit.

Ompung pun sampai di tempat yang ia tuju. Ia bertekad untuk tinggal didataran itu selamanya dan akan membangun kampung baru. Setelah sekian tahun menetap, barulah Ompung bertemu dengan penduduk daerah itu yang masih terbelakang cara hidupnya. Meskipun demikian, 
mereka tidak menganggu Ompung, bahkan sangat bersahabat.

Akhirnya, Ompung pun meninggal dunia di daerah yang ia sebut Lappung, kini bernama Sekala Berak atau Dataran Tinggi Belalau di Lampung Barat.

Menurut cerita rakyat di daerah itu, bahkan para ahli sejarah tentang Lampung, nama Lampung itu sendiri berasal dari nama Ompung Silamponga. Akan tetapi ada juga yang mengatakan bahwa nama Lampung berasal dari ucapan Ompung Silamponga ketika berada di atas bukit, setelah melihat adanya dataran yang luas. Perlu diketahui, Guru besar Fakultas Hukum Universitas Lampung, Prof Hilman Hadikusuma, SH, memasukkan legenda Ompung Silamponga sebagai teori ketiganya tentang asalusul Lampung. Beliau menyebutkan bahwa Sekala Berak adalah perkampungan pertama orang Lampung. Penduduknya disebut orang Tumi atau Buay Tumi.

After telling the story above, we convey the moral message from the story. The moral message of the Lampung Folk Story: The origin of the city of Lampung is that in our lives we must be steadfast and must not easily give up in our quest for a new life. Wherever he is, he can carry on his life, which is important to try and work.

Based on observations, children will participate in the activities carefully and enthusiastically. Observations are not only made in the classroom but also seen in theinteractions between their peers and the interaction of children with teachers. Children becomes more caring, happy to help friends, and occasionally reminds friends who make mistakes by connecting with the story being told.

Through storytelling it is hoped that children will recognize, understand and be able to feel the values contained in the story, so good character values will be embedded in the child. The habit of telling stories or storytelling about folklore needs to be done at school, especially at home, so that communication between teachers, parents, and children can be established in instilling the children's character.

\section{CONCLUSION}

Character building in childhood needs to be done because they are the next generation of the nation. Character building through folklore is a good idea because we dive into the world of children. It is hoped that children can care more and have good character. The Indonesian nation must be built by prioritizing character development because this character building will make Indonesia a great, advanced, and glorious, dignified nation. Developing characters to children must be in line with the nation's character. Because it is wrapped in the noble personality of the nation. Even though we are in the current era. The habit of telling stories or storytelling about folklore needs to be done at school, especially at home, so that communication between teachers, parents, and children can be established in instilling the children's character.

\section{ACKNOWLEDGMENT}

We thank all those who have assisted in data collection in the field. In addition, we would like to thank the Department of early childhood education, the Ministry of education and culture, Republic of Indonesia for giving permission and funding for this scientific publication.

\section{REFERENCES}

Bredekamp, S. (1987). Developmentally appropriate practice in early childhood programs serving children from brith to age 8. Washington: National Association for the Education of Young Children.

Bredekamp, S., \& Copple, C. (1987). Developmentally appropriate practice in early childhood programs. Washington: National Association for the Education of Young Children.

DeVries, R., \& Zan, B. (1994). Moral classroom, moral children: Creating a constructivist moral atmosphere in early childhood. New York: Teachers Collage Press.

DeVries, R., Zan, B., Hildebrandt, C., Edmiaston, R., \& Sales, C. (eds). (2002). Developing constructivist early childhood curriculum: Practical principles and activities. New York: Teachers Collage Press.

Dewantara, K. H. (1977). Pengajaran budi pekerti. Yogyakarta: Taman Siswa.

Dewantara, K. H. (2013). Pemikiran, konsepsi, keteladanan, sikap merdeka: Jilid I pendidikan. Yogyakarta: Universitas Sarjanawiyata Tamansiswa (UST-Press).

Dwiningrum, S. I. A. (2013). Nation's character education based on the social capital theory. Journal Asian Social Science, 9(12), 144-155.

Fosnot, C. T. (2005). Constructivism: Theory, perspectives, and practice. New York: Teachers Collage Press.

Mentari, A. (2017). Study thought Ki Hajar Dewantara on the concept of character and national education. 4th International Conference on English Literature and Humanities, 480-484. Retrieved from: https://doi.org/10.15242/DIRPUB.EA0417033 
Nurmalisa, Y., Mentari, A., Nurhayati, \& Yanzi, H. (2019). Peranan pendidikan budi pekerti dalam pembinaan warga negara cerdas yang berkarakter di era revolusi industri 4.0. Prosiding Seminar Nasional Pendidikan FKIP 2019, 413-426.

Prahara, N. E. (2015). Asal Mula Lampung. Retrieved from:

http://www.ceritadongenganak.com/2015/03/ompungsilamponga-asal-mula-nama-lampung.html

Rawana, J. R. E., Franks, J. L., Brownlee, K., Rawana, E. P. \& Neckoway, R. (2011). The aplication of a strength-based approach of students' behaviours to the development of a character education curriculum for elementary and secondary school. Journal of Education Thought, 45, 127-144

Samani, M., \& Hariyanto (2016). Konsep dan model pendidikan karakter. Bandung: PT Remaja Rosdakarya Offset.

Soedarsono, S. (2009). Karakter mengantar bangsa dari gelap menuju terang. Jakarta: PT Elex Media Komputindo. 